\begin{tabular}{|l|l|l||}
\hline \multicolumn{2}{|c|}{ PublisherInfo } \\
\hline \hline PublisherName & $:$ & BioMed Central \\
\hline \hline PublisherLocation & $:$ & London \\
\hline \hline PublisherImprintName & $:$ & BioMed Central \\
\hline \hline
\end{tabular}

\title{
Survival signals
}

\begin{tabular}{|l|l|l||}
\hline \multicolumn{2}{|c|}{ ArticleInfo } \\
\hline \hline ArticleID & $:$ & 4553 \\
\hline \hline ArticleDOI & $:$ & $10.1186 /$ gb-spotlight-20020813-01 \\
\hline \hline ArticleCitationID & $:$ & spotlight-20020813-01 \\
\hline \hline ArticleSequenceNumber & $:$ & 219 \\
\hline \hline ArticleCategory & $:$ & Research news \\
\hline ArticleFirstPage & $:$ & 1 \\
\hline \hline ArticleLastPage & $:$ & 2 \\
\hline \hline & & RegistrationDate : 2002-8-13 \\
\hline ArticleHistory & $:$ & OnlineDate \\
\hline \hline ArticleCopyright & $:$ & BioMed Central Ltd2002-8-13 \\
\hline \hline ArticleGrants & $:$ & \\
\hline \hline ArticleContext & $:$ & 130593311 \\
\hline \hline
\end{tabular}




\section{Jonathan B Weitzman}

Email: jonathanweitzman@hotmail.com

Signalling by the c-Jun N-terminal kinase (JNK) pathway has been implicated in the cellular response to stress and the induction of apoptosis. In an Advanced Online Publication in Nature Genetics, Hess et al. demonstrate a clear role for JNK1 in cell survival (Nature Genetics, 5 August 2002, doi:10.1038/ ng946). They used knockout mice lacking the Mapk8/jnkl gene to investigate the role of JNK signalling in B-cell transformation induced by the leukemogenic oncogene $B C R-A B L$. They observed reduced $B C R-A B L$ transformation of pre-B cells in vitro in the absence of JNK1, and altered leukemia in vivo. JNK1 deletion resulted in decreased cell survival and reduced expression of the anti-apoptotic Bcl-2 protein. Restoring Bcl-2 expression, using transgenic animals, restored B-cell leukemogenesis.

\section{References}

1. The JNK signal transduction pathway.

2. Nature Genetics, [http://www.nature.com/ng/] 